JURNAL EKONOMI

EFEKTIF
ISSN : $2622-8882$, E-ISSN : 2622-9935

Jurnal Ekonomi Efektif, Vol. 2, No. 1, Oktober 2019

(a) Prodi Manajemen Fakultas Ekonomi Universitas

Pamulang

\title{
PENGARUH CAPITAL ADEQUACY RATIO DAN NON PERFORMING LOAN TERHADAP RETURN ON ASSETS PADA PT. BANK SINARMAS TBK PERIODE TAHUN 2011-2017
}

\author{
${ }^{1}$ N. Rusnaeni, Sefti Riana Sari \\ 1.
}

\begin{abstract}
ABSTRAK
Tujuan dari penelitian ini adalah untuk mengetahui apakah terdapat pengaruh yang signifikan antara Capital Adequacy Ratio dan Non Performing Loan Terhadap Return On Asset pada PT Bank Sinarmas Tbk. Objek yang dilakukan dalam penelitian ini adalah data laporan keuangan PT Bank Sinarmas Tbk Periode 2011-2017.

Metode analisis data yang digunakan adalah penelitian menggunakan analisis statistik deskriptif, analisis regresi linear berganda, koefisien korelasi, koefisien determinasi, uji asumsi klasik, pengujian hipotesis uji $t$ dan uji f dengan menggunakan SPSS Versi 20.

Berdasarkan hasil perhitungan analisis regresi linear berganda $\mathrm{Y}=0,020+0,077 \mathrm{X} 1-$ $0,045 \mathrm{X} 2+$ e dan koefisien korelasi antara variabel independen Capital Adequacy Ratio $\left(\mathrm{X}_{1}\right)$ dan Non Performing Loan $\left(\mathrm{X}_{2}\right)$ terhadap variabel dependen Return On Asset (Y) didapat nilai $\mathrm{R}$ sebesar 0,527 dengan koefisien determinasi sebesar 0,278 yang artinya 27,8\% Return On Asset dipengaruhi oleh Capital Adequacy Ratio (CAR) dan Non Performing Loan (NPL), sedangkan sisanya sebesar $72,2 \%$ dipengaruhi oleh faktor lain yang tidak dijelaskan dalam penelitian ini. Berdasarkan hasil uji $\mathrm{F}$ secara simultan menunjukkan bahwa nilai $\mathrm{F}_{\text {hitung }}$ lebih kecil dari $\mathrm{F}_{\text {tabel }}(0,769<6,94)$ dengan nilai signifikansi 0,522 $>0,05$. Sedangkan hasil uji $t$ secara parsial CAR dan NPL tidak berpengaruh signifikan terhadap ROA, karena kedua variabel tersebut memiliki nilai signifikansi lebih besar dari taraf nyata 0,05 .
\end{abstract}

\section{Kata Kunci : Capital Adequacy Ratio, Non Performing Loan, dan Return On Asset}

\section{ABSTRACT}

The purpose of this study is to find out whether there is a significant influence between the Capital Adequacy Ratio and Non Performing Loans Against Return On Asset at PT Bank Sinarmas Tbk. The object carried out in this study is the financial statements of PT Bank Sinarmas Tbk Period 2011-2017.

The data analysis method used is research using descriptive statistical analysis, multiple linear regression analysis, correlation coefficient, determination coefficient, classical assumption test, hypothesis testing t test and f test using SPSS Version 20.

Based on the results of multiple linear regression analysis $Y=0,020+0,077 X 1-$ $0,045 X 2+e$ and the correlation coefficient between the independent variables Capital Adequacy Ratio $\left(X_{1}\right)$ and Non Performing Loans $\left(X_{2}\right)$ on the dependent variable Return On Assets $(Y)$ obtained an $R$ value of 0,527 with a coefficient of determination of 0,278 which 
means 27,8\% Return on Asset is influenced by the Capital Adequacy Ratio (CAR) and Non Performing Loans (NPL), while the remaining 72,2\% is influenced by other factors not explained in this study. Based on the results of the $F$ test simultaneously indicate that the value of $F_{\text {count }}$ is smaller than $F_{\text {table }}(0,769<6,94)$ with a significance value of $0,804>0,05$. While the results of the partial t test of CAR and NPL do not have a significant effect on ROA, because the two variables have a significance value greater than the real level of 0,05.

\section{Keywords : Capital Adequacy Ratio, Non Performing Loan, dan Return On Asset}

\section{PENDAHULUAN}

\section{A. Latar Belakang}

Analisis laporan keuangan Bank Sinarmas dapat dilakukan dengan menggunakan rasio keuangan. Rasio-rasio yang digunakan untuk menilai kinerja keuangan Bank Sinarmas itu seperti rasio likuiditas, rasio leverage, rasio aktivitas dan rasio profitabilitas. Analisis rasio memungkinkan manajer keuangan dan pihak yang berkepentingan untuk mengevaluasi kondisi keuangan, dimana analisis rasio ini akan menunjukkan kondisi sehat tidaknya suatu Bank. Beberapa penelitian menunjukkan bahwa rasio keuangan terbukti berperan dalam penilaian kinerja bank, termasuk risiko yang menyertai dalam kegiatan usaha bank. Pendapatan (keuntungan), dalam beberapa penelitian umumnya diproksikan dengan menggunakan rasio keuangan Return On Assets (ROA). Return On assets (ROA) merupakan salah satu rasio profitabilitas yang dapat mengukur kemampuan perusahaan dalam menghasilkan laba dari aktiva yang digunakan. Return on Assets mampu mengukur kemampuan perusahaan menghasilkan keuntungan pada masa lampau untuk kemudian diproyeksikan di masa yang akan datang. Menurut Kasmir (2012:203), menjelaskan bahwa yang mempengaruhi Return On Assets (ROA) adalah hasil pengembalian atas investasi atau yang disebut sebagai Return On Assets (ROA) dipengaruhi oleh margin laba bersih danperputaran total aktiva karena apabila Return On Assets (ROA) rendah itu disebabkan oleh rendahnya margin laba yang diakibatkan oleh rendahnya margin laba bersih yang diakibatkan oleh rendahnya perputaran total aktiva.

Return On Assets (ROA) memfokuskan kemampuan perusahaan untuk memperoleh earning dalam operasi perusahaan. hubungan antara profitabilitas (ROA) terhadap Capital Adequacy Ratio (CAR) suatu bank adalah positif, dimana jika profitabilitas (ROA) suatu bank meningkat maka Capital Adequacy Ratio (CAR) akan meningkat juga. Jadi apabila profitabilitas (ROA) suatu bank terus meningkat maka modal bank tersebut akan terus bertambah dan dapat digunakan untuk kegiatan operasional yang akan dapat menghasilkan laba atau keuntungan. Dimana standar besarnya Capital Adequacy Ratio (CAR) yaitu sebesar 8\%. Sesuai dengan Surat Edaran BI No.25/5/BPP tanggal 29 Mei 1993 besarnya Capital Adequacy Ratio (CAR) yang harus dicapai oleh suatu bank minimal 8\% sejak akhir tahun 1995 dan sejak akhir tahun 1997 Capital Adequacy Ratio (CAR) yang harus dicapai minimal 9\%.

Sementara itu, penilaian kesehatan perbankan mencakup beberapa faktor yaitu faktor permodalan Capital Adequacy Ratio (CAR) yang mewakili modal, faktor kualitas asset Non Performing Loan (NPL) yang mewakili risiko kredit. Salah satu komponen faktor permodalan adalah kecukupan modal.Rasio untuk menguji kecukupan modal bank yaitu rasio Capital Adequacy Ratio (CAR). Semakin efisien modal bank yang digunakan untuk aktivitas operasional mengakibatkan bank mampu meningkatkan pemberian kredit sehingga akan mengurangi tingkat risiko bank. Tingkat Capital Adequacy Ratio yang ideal akan meningkatkan kepercayaan masyarakat sebagai pemilik dana terhadap bank sehingga masyarakat akan memiliki keinginan yang lebih untuk menyimpan dananya di bank, yang pada akhirnya bank akan memiliki kecukupan dan untuk menjalankan kegiatan operasionalnya 
seperti pemberian kredit kepada masyarakat yang memungkinkan bank untuk dapat memperoleh laba lebih dari kenaikan pendapatan bunga kredit.

Dengan mengetahui pentingnya Capital Adequacy Ratio (CAR) tersebut, maka pihak manajemen bank perlu memperhatikan besarnya Capital Adequacy Ratio yang ideal karena apabila terlalu tinggi akan mengakibatkan meningkatnya dana yang menganggur dan apabila terlalu rendah akan berdampak pada hilangnya kepercayaan masyarakat. Artinya sebuah bank disibukkan oleh nasabah bank yang ingin menarik kembali dananya di bank secara bersamaan dan besar-besaran sehingga dana pihak ketiga dapat turun secara drastis, sementara besarnya penyaluran kredit bergantung kepada besarnya simpanan (dana pihak ketiga) yang dapat dihimpun oleh bank. Sehingga kemudian dapat menjatuhkan likuiditas bank dan menghambat aktivitas penyaluran kredit (Darmawi 2011:91).

Sedangkan memperhatikan besarnya Capital Adequacy Ratio (CAR), manajemen bank juga perlu untuk memprhatikan besarnya Non Performing Loan (NPL). Non Performing Loan merupakan salah satu indikator kesehatan kualitas aset bank. Indikator tersebut merupakan rasio keuangan pokok yang dapat memberikan informasi penilaian atas kondisi permodalan, rentabilitas, risiko kredit, risiko pasar dan likuidasi. Dengan Non Performing Loan akan membuat bank dapat menilai berapa banyak modal yang dimiliki oleh bank tersebut. Non Performing Loan berkaitan dengan kredit bermasalah, tidak semua bank memiliki nasabah yang rajin membayar kreditnya, namun ada juga nasabah yang terlambat membayar kreditnya, tidak hanya sebulan atau dua bulan namun sampai berbulan-bulan. Semakin banyak angka rasio Non Performing Loan pada sebuah bank bisa di pastikan bahwa ada yang salah dengan fungsi kinerja bank tersebut, dampak negatif yang ditimbulkan pun semakin banyak. Sedangkan semakin kecil rasio persentasi dari sebuah Non Performing Loan bisa dipastikan bahwa kinerja bank dan fungsi bank tersebut sudah bekerja dengan baik. Fungsi dasar sebuah bank adalah sama yaitu untuk menghubungkan antara kedua belah pihak, pihak pertama adalah pihak yang memiliki kelebihan dana dan ingin menyimpanm uangnya di bank sedangkan pihak kedua adalah pihak yang membutuhkan dana sehingga pihak tersebut mengajukan kredit atau pinjaman ke bank.

Tolak ukur penilaian kinerja bank yang merupakan variabel terikat (variable dependen) dalam penelitian ini adalah rasio Return On Assets (ROA). Alasan dipilihnya Return on Assets sebagai variabel terikat karena Return on Assets merupakan rasio yang menunjukkan kinerja bank. Return on Assets merupakan perbandingan (rasio) laba sebelum pajak selama 12 bulan terakhir terhadap rata-rata volume usaha dalam periode yang sama. Return on Assets yang semakin besar, menunjukkan kinerja bank semakin baik, karena tingkat pengembalian semakin besar. Oleh karena itu, Return On Assets merupakan rasio yang menghasilkan keuntungan dengan memanfaatkan aktiva yang dimilikinya.

Rasio-rasio pada PT Bank Sinarmas, Tbk. Rasio Capital Adequacy Ratio (CAR) mengalami fluktuasi pada tahun 2013 sampai dengan 2017 dimana (CAR) pada PT Bank Sinarmas Tbk masih bisa terkendali, terlihat dari tingkat penurunan dan kenaikan yang tidak terlalu jauh sehingga bank ini masih bisa mengatasi kemungkinan risiko yang akan terjadi, sedangkan rasio Non Performing Loan (NPL) juga mengalami perubahan yang tidak konsisten, ada penurunan dan kenaikan, pada tahun 2014 sampai dengan 2017 terlihat jelas tingkat kenaikan (NPL) pada PT Bank Sinarmas Tbk yang besar ini menunjukkan bahwa menurunnya laba yang akan diterima oleh bank, sedangkan rasio Return On Assets (ROA) mengalami naik turun pada tahun 2012 sampai 2017 dimana (ROA) pada PT Bank Sinarmas Tbk ini masih belum bisa dikatakan baik dikarenakan (ROA) akan dikatakan baik tidaknya apabila dapat membandingkan dengan (ROA) perusahaan lain yang sejenis, jika (ROA) Bank Sinarmas berada diatas perusahaan sejenis maka (ROA) Bank Sinarmas baru dapat dikatakan baik. 


\section{B. Identifikasi Masalah}

Penurunan Rasio Capital Adequacy Ratio (CAR) pada tahun 2015.

1. Naiknya Rasio Non performing Loan (NPL) pada tahun 2015.

2. Peningkatan Capital Adequacy Ratio (CAR) tidak diikuti dengan peningkatan Return On Assets (ROA).

3. Industri perbankan merupakan industri yang syarat dengan risiko karena melibatkan dana masyarakat.

\section{Rumusan Masalah}

Bagaimana pengaruh Capital Adequacy Ratio (CAR) terhadap Return on Asset (ROA)

PT. Bank Sinarmas, Tbk periode 2011-2017?

1. Bagaimana pengaruh Non Performing Loan (NPL) terhadap Return on Asset (ROA) PT. Bank Sinarmas, Tbk periode 2011-2017?

2. Bagaimana pengaruh Capital Adequacy Ratio (CAR) dan Non Performing Loan (NPL) terhadap Return On Assets (ROA) PT. Bank Sinarmas, Tbk periode 2011-2017?

\section{Kerangka Berfikir}

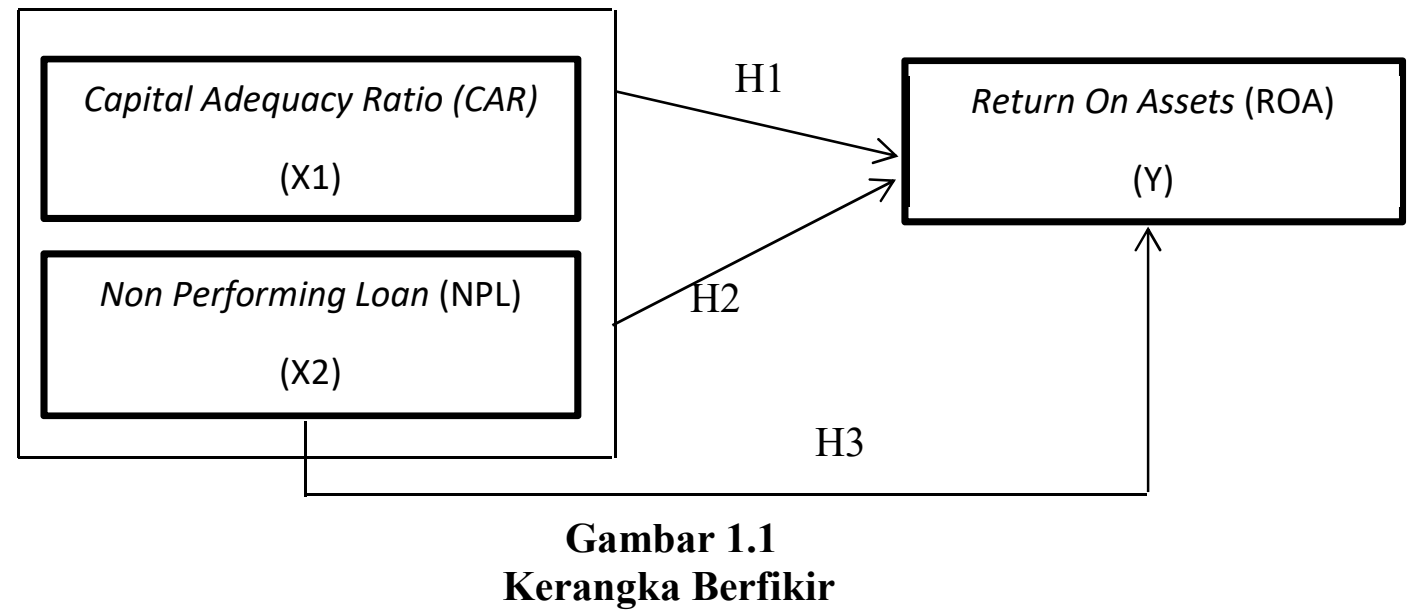

\section{E. Hipotesis}

1. $\mathrm{H}_{\mathrm{o}}: \beta_{1}=0$ tidak terdapat pengaruh Capital Adequacy Ratio (CAR) terhadap Return On Assets (ROA) secara parsial pada PT. Bank Sinarmas, Tbk.

$\mathrm{H}_{\mathrm{a}}: \beta_{1} \neq 0$ terdapat pengaruh Cpital Adequacy Ratio (CAR) terhadap Return On Assets (ROA) secara parsial pada PT. Bank Sinarmas, Tbk.

2. $\mathrm{H}_{\mathrm{o}}: \beta_{2}=0$ tidak terdapat pengaruh Non Performing Loan (NPL) terhadap Return On Assets (ROA) secara parsial pada PT. Bank Sinarmas, Tbk.

$\mathrm{H}_{\mathrm{a}}: \beta_{2} \neq 0$ terdapat pengaruh Non Performing Loan (NPL) terhadap Return On Assets (ROA) secara parsial pada PT. Bank Sinarmas, Tbk.

3. $\mathrm{H}_{\mathrm{o}}: \beta_{3}=0$ tidak terdapat pengaruh Capital Adequacy Ratio (CAR) dan Non Performing Loan (NPL) terhadap Return On Assets (ROA) secara simultan pada PT. Bank Sinarmas, Tbk. $\mathrm{H}_{\mathrm{a}}: \beta_{3} \neq 0$ terdapat pengaruh Capital Adequacy Ratio (CAR) dan Non Performing Loan (NPL) terhadap Return On Assets (ROA) secara simultan pada PT. Bank Sinarmas, Tbk 


\section{TINJAUAN PUSTAKA}

\section{A. Laporan Keuangan}

Menurut Ikatan Akuntan Indonesia (2009:1) laporan keuangan meliputi bagian proses dari laporan keuangan. Laporan keungan yang lengkap meliputi neraca, laporan laba rugi, laporan perubahan ekuitas, laporan perubahan posisi keuangan (yang dapat disajikan dalam berbagai cara misalnya sebagai laporan arus kas/laporan arus dana), catatan dan laporan lain serta materi penjelasan yang merupakan bagian integral dari laporan keuangan. Sedangkan menurut Harahap (2009:105), laporan keuangan menggambarkan kondisi keuangan dan hasil usaha suatu perusahaan pada saat tertentu atau jangka waktu tertentu. Adapun jenis laporan keuangan yang lazim dikenal adalah neraca, laporan laba rugi, perubahan ekuitas, laporan arus kas, laporan posisi keuangan.

Menurut Munawir (2010:5), pada umumnya laporan keuangan itu terdiri dari neraca dan perhitungan laba-rugi serta laporan perubahan. ekuitas. Neraca menunjukka/menggambarkan jumlah aset, kewajiban dan ekuitas dari suatu perusahaan pada tanggal tertentu. Sedangkan perhitungan (laporan) laba-rugi memperlihatkan hasil-hasil yang telah dicapai oleh perusahaan serta beban yang terjadi selama periode tertentu dan laporan perubahan ekuitas menunjukan sumber dan penggunaan atau alasan-alasan yang menyebabkan perubahan ekuitas perusahaan

Susilo dalam bukunya "Bank dan Lembaga Keungan Lainnya" menjelaskan bahwa setiap perusahaan, baik bank maupun non bank pada suatu waktu (periode tertentu) akan melaporkan kegiatan keuangannya. Laporan keuangan ini bertujuan untuk memberikan informasi keuangan perushaan, baik kepada pemilik, manajemen maupun pihak luar yang berkepentingan terhadap laoran tersebut. Disamping melakukan kegiatan menghimpun dan menyalurkan dana, bank juga memberikan penawaran jasa-jasa perbankan yang lain kepada masyarakat. Jasa-jasa yang ditawarkan oleh perbankan ini erat kaitannya dengan kagiatan perekonomian masyarakat secara umum. Jasa-jasa bank ini anatar lain dapat berupa jasa pengiriman uang, jasa penitipan barang berharga, jasa pemberian jaminan bank, dan jasa penyelesaian tagihan.

Kemudian laporan keuangan juga memberikan informasi tentang hasil-hasil usaha yang diperoleh bank dalam suatu periode tertentu dan biaya-biaya atau beban yang dikeluarkan utnuk memperoleh hasil tersebut. Informasi ini akan termuat dalam laporan laba rugi. Laporan bank juga memberikan gambaran tentang arus kas suatu bank yang tergambar dalam laporan arus kas (A.Totok Budi Santoso, Sri Susilo, Sigit Triandaru, 2009). Berdasarkan pengertian di atas dapat disimpulkan bahwa laporan keuangan untuk perusahaan terdiri laporan-laporan yang melaporkan posisi keuangan perusahaan pada suatu waktu terntentu, yang dilaporkan dalam neraca dan perhitungan laba rugi serta laporan perubahaan ekuitas dan laporan arus kas, dimana neraca menunjukkan jumlah asset kewajiban dan ekuitas perusahaan. Laporan laba rugi menunjukkan hasil operasi perusahaan selama periode tertentu. Sedangkan laporan peruabahan ekuitas menunjukkan sumber dan penggunaan atau alasan-alasan yang menyebabkan peubahan ekuitas perusahaan.

\section{B. Analisis Rasio Keuangan}

Rasio keuangan ini sangat penting gunanya untuk melakukan analisis terhadap kondisi keuangan perusahaan. Rasio keuangan merupakan cara yang paling umum digunakan dalam menganalisis laporan keuangan. Analisis rasio menggambarkan hubungan sistematis antara suatu jumlah dengan jumlah lainnya. Perhitungan yang digunakan dalam analisis ini sebenarnya sederhana, namun interpestasi terhadap rasio tersebut. Analisis rasio keuangan menurut Subramanyam dan Wild (2012:4) yaitu: "Analisis rasio keuangan adalah Bagian dari analisis bisnis atas prospek dan risiko perusahaan untuk kepentingan pengambilan keputusan 
dengan menstrukturkan tugas analisis melalui evaluasi atas bisnis lingkungan perusahaan, strateginya, serta posisi dan kinerja keuangannya".

Menurut Munawir (2010:64) Analisis rasio keuangan adalah: "Analisis rasio keuangan adalah rasio yang menggambarkan suatu hubungan atau pertimbangan (mathematical relationship) antara suatu jumlah tertentu dengan jumlah yang lain, denganmenggunakan alat analisa berupa rasio yang menjelaskan gambaran kepada penganalisa tentang baik atau buruk keadaan keuangan perusahaan terutama apabila angka rasio tersebut dibandingkan dengan angka rasio pembanding yang digunakan sebagai standar".

Pengertian analisis laporan keuangan menurut Harahap (2015:190) adalah: Uraian pospos laporan keuangan yang menjadi unit informasi yang lebih kecil, digunakan untuk melihat hubungan yang bersifat signifikan atau yang mempunyai makna antara satu dengan yang lain baik antara data kuantitatif maupun data non-kuantitatif dengan tujuan untuk mengetahui kondisi keuangan lebih dalam yang sangat penting dalam proses menghasilkan keputusan yang tepat. Berdasarkan pengertian diatas dapat disimpulkan bahwa analisis laporan keuangan merupakan suatu proses menelaah laporan keuangan utuk melihat berbagai hubungan dan kecenderungan yang dapat memberikan pertimbangan kepada keberhasilan perusahaan di masa depan.

\section{Lembaga Keungan Bank}

Bank adalah badan usaha yang menghimpun dana dari masyarakat dalam bentuk simpanan dan menyalurkan ke masyarakat dalam bentuk kredit atau dalam bentuk lainnya dalam rangka meningkatkan taraf hidup masyarakat Dr. Kasmir (2012:4). Menurut Tarwan (2010:7) bank adalah lembaga yang berperan sebagai lembaga keuangan (financial intermediary) antara pihak-pihak yang memiliki kelebihan dana (surplus spending unit) dengan mereka yang membutuhkan dan a(deficit spending unit) serta berfungsi untuk memperlancar lalu lintas pembayaran giral.

Menurut Dictionary Of Banking and Financial Service by Jerry Rosenberg dalam Taswan (2010:6) menyatakan bahwa bank adalah lembaga yang menerima simpanan giro, deposito, dan membayar atas dasar dokumen yang ditarik pada orang atau lembaga tertentu, mendiskonto surat berharga, memberikan pinjaman dan menanamkan dananya dalam surat berharga.

\section{Capital Adequacy Ratio}

Menurut Kasmir (2010:232) pengertian rasio kecukupan modal dapat di artikan sebagai rasio yang digunakan untuk mengukur permodalan dan cadangan penghapusan dalam menanggung pengkreditan, terutama resiko yang terjadi karena bunga gagal ditagih. Menurut Dendawijaya (2009:121) Rasio kecukupan modal (CAR) merupakan rasio yang memperlihatkan seberapa jauh seluruh aktiva bank yang mengandung resiko (kredit penyertaan, surat berharga, tagihan pada bank lain) untuk dibiayai dari dana modal bank sendiri. Menurut Darmawi (2011:91), salah satu komponen faktor permodalan adalah kecukupan modal. Rasio untuk menguji kecukupan modal bank yaitu rasio CAR (Capital Adequacy Ratio).

Menurut Hasibuan (2009:58), CAR adalah salah satu cara untuk menghitung apakah modal yang ada pada suatu bank telah memadai atau belum. Menurut Bank Indonesia (Nomor 9/13/PBI/2007), CAR adalah penyediaan modal minimum bagi bank didasarkan pada risiko aktiva dalam arti luas, baik aktiva yang tercantum dalam neraca maupun aktiva yang bersifat administratif sebagaimana tercermin pada kewajiban yang masih bersifat kontijen dan/atau komitmen yang disediakan oleh bank bagi pihak ketiga maupun risiko pasar. 
Menurut peraturan Otoritas Jasa Keuangan (Nomor/14/2017) juga menetapkan tiga status pengawasan bank, yaitu pengawasan normal, intensif, atau khusus. Bank dikatakan intensif jika memenuhi kriteriayang ditetapkan OJK, yaitu: Rasio Kewajiban Penyediaan Modal Minimum (KPMM) sama dengan atau lebih besar 8\% namun $<$ dari rasio KPMM sesuai profit risiko bank yang wajib dipenuhi. Dari pengertian diatas dapat disimpulkan (CAR) adalah rasio kinerja bank untuk mengukur kecukupan modal yang dimiliki bank untuk menunjang aktiva yang mengandung atau menghasilkan risiko, seperti kredit yang diberikan kepada nasabah.

\section{E. Non Performing Loan}

Dalam melakukan pemberian kredit kepada nasabahnya, bank akan dihadapkan pada risiko kredit yang tidak mampu dibayar oleh debitur yang sehingga menimbulkan kredit bermasalah. Pengertian Non Performing Loan (NPL) menurut Mahmoedin (2010:1) Non Performing Loan (NPL) kredit yang dapat menimbulkan persoalan, bukan hanya terhadap bank selaku lembaga pemberi kredit, tetapi juga terhadap nasabah penerima kredit.

Sedangkan menurut Kasmir (2013:155) pengertian Non Performing Loan (NPL) adalah kredit yang didalamnya terdapat hambatan yang disebabkan oleh 2 unsur yakni dari pihak perbankan dalam menganalisis maupun dari pihak nasabah yang dengan sengaja atau tidak sengaja dalam kewajibannya tidak melakukan pembayaran.

Menurut Herman Darmawi (2011:16) pengertian Non Performing Loan (NPL) adalah salah satu pengukuran dari rasio risiko usaha bank yang menunjukkan besarnya risiko kredit bermasalah yang ada pada suatu bank. Kredit bermasalah diakibatkan oleh ketidak lancaran pembayaran. Menurut Peraturan Bank Indonesia Nomor 6/10/PBI/2004 tanggal 12 April 2004 tentang Sistem Penilaian Tingkat Kesehatan Bank Umum, menetapkan bahwa rasio kredit bermasalah (NPL) adalah sebesar 5\%.

Dari penyataan diatas dapat dikatakan bahwa pengertian non performing loan (NPL) merupakan rasio untuk mengukur besarnya risiko kredit bermasalah pada suatu bank yang diakibatkan oleh ketidak lancaran dalam pembayaran pokok pinjaman yang dilakukan oleh pihak nasabah sehingga kinerja bank menurun dan menjadi tidak efisien. Pokok pinjaman dan bunga yang secara langsung dapat menurunkan kinerja bank dan menyebabkan bank tidak efisien.

\section{F. Return On Assets (ROA)}

Return On Asset (ROA) merupakan rasio yang menunjukkan hasil (return) atas jumlah aktiva yang digunakan dalam perusahaan. Return On Asset (ROA) merupakan suatu ukuran tentang efektivitas manajemen dalam mengelolah investasinya.

Di samping itu hasil pengembalian investasi menunjukkan produktivitas dari seluruh dana perusahaan, baik modal pinjaman maupun modal sendiri. Semakin rendah (kecil) rasio ini semakin kurang baik, demikian pula sebaliknya. Artinya rasio ini digunakan untuk mengukur efektivitas dari keseluruhan operasi perusahaan. Menurut Munawir (2010:89) Retutrn On Asset adalah sama dengan Return On Investmendalam analisa keuangan mempunyai arti yang sangat penting sebagai salah satu teknik analisa keuangan yang bersifat menyeluruh (komprehensif). Analisis ini sudah merupakan teknik analisa yang lazim di gunakan oleh pimpinan perusahaan untuk mengukur efektivitas dari keseluruhan operasi perusahaan.

Menurut Fahmi (2012: 98) Return on asset sering juga disebut sebagai return on investment, karena ROA ini melihat sejauh mana investasi yang telah ditanamkan mampu memberikan pengembalian keuntungan sesuai dengan yang diharapkan dan investasi tersebut sebenarnya sama dengan aset perusahaan yang ditanamkan atau ditempatkan. Menurut I Made 
Sudana (2011:22), Return On Assets (ROA) menunjukkan kemampuan perusahaan dengan menggunakan seluruh aktiva yang dimiliki untuk menghasilkan laba setelah pajak.

Menurut Eduardus Tandelilin (2010:372), Return On Assets menggambarkan sejauh mana kemampuan aset-aset yang dimiliki perusahaan bisa menghasilkan laba. Dari pengertian di atas dapat disimpulkan bahwa pengertian dari Return On Asset (ROA) adalah rasio yang menunjukkan seberapa banyak laba bersih yang bisa diperoleh dari seluruh kekayaan yang dimiliki perusahaan. Karena itu digunakan angka laba setelah pajak dan rata-rata kekayaan perusahaan.

\section{METODE PENELITIAN}

Lokasi penelitian yang dilakukan dalam penelitian ini dilakukan pada PT Bank Sinarmas Tbk dalam kurun waktu 2011-2017, sebuah perusahaan yang bergerak dibidang keuangan yang beralamat di JL. M.H Thamrin kav 51, Menara 1, Lantai 1 \& 2, Jakarta 10350 - Indonesia. Untuk memperoleh data dan informasi dalam penelitian ini penulis mengambil data sekunder laporan keuangan PT Bank Sinarmas Tbk yang telah di audit dan di publikasikan melalui websait PT Bank Sinarmas Tbk.

Penelitian ini dilakukan secara bertahap diawali dengan observasi pendahuluan, pengajuan surat izin, pengumpulan keputusan konsultasi dan perbaikan-perbaikan dan pengolahan data. Data yang diambil adalah data laporan keuangan periode 2011-2017. Penelitian ini dilakukan dari bulan Oktober 2018 sampai dengan bulan Januari 2019, yang dijadikan populasi dalam penelitian ini adalah Data Laporan Keuangan PT Bank Sinarmas Tbk, teknik pengambilan sampel, sehingga generalisasi kepada populasi yang diteliti. Maknanya sampel yang diambil dapat mewakili atau representatif bagi populasi tersebut. Sedangkan menurut Sugiyono (2011:84) Sampling Purposive adalah teknik penentuan sampel dengan pertimbangan tertentu. Sampel yang digunakan pada penelitian ini adalah laporan keuangan yang terdiri dari neraca dan laporan laba rugi PT Bank Sinarmas Tbk periode 2011-2017.

\section{PEMBAHASAN DAN HASIL PENELITIAN}

\section{A. Analisis Data}

\section{Analisis Statistik Deskriptif}

Tabel 4.1

Analisis Statistik Deskriptif

\begin{tabular}{|l|r|r|r|r|r|}
\hline \multicolumn{7}{|c|}{ Descriptive Statistics } \\
\hline & $\mathrm{N}$ & Minimum & Maximum & Mean & $\begin{array}{c}\text { Std. } \\
\text { Deviation }\end{array}$ \\
\hline CAR & 7 & 13.09 & 22.78 & 18.1571 & 3.02299 \\
\hline NPL & 7 & .89 & 3.22 & 2.3529 & .90199 \\
\hline ROA & 7 & .85 & 1.88 & 1.3071 & .40701 \\
\hline $\begin{array}{l}\text { Valid N } \\
\text { (listwise) }\end{array}$ & 7 & & & & \\
\hline
\end{tabular}

Berdasarkan tabel 4.1 diatas menunjukkan jumlah data $(\mathrm{N})$ sebanyak 7 data. Dari 7 data tersebut nilai terkecil (Minimum) variabel (CAR) sebesar 13,09\%, variabel (NPL) sebesar $0,89 \%$ dan variabel (ROA) sebesar 0,85\%. nilai terbesar (Maximum) variabel (CAR) sebesar 22,78\%, variabel (NPL) sebesar 3,22\% dan variabel (ROA) sebesar $1,88 \%$. sedangkan rata-rata nilai variabel (CAR) sebesar $3.02299 \%$, variabel (NPL) sebesar $2.3529 \%$ dan variabel (ROA) sebesar $1,3071 \%$. 


\section{Analisis Regresi Linier Berganda}

Tabel 4.2

Analisis Regresi Linier Berganda

\begin{tabular}{|c|c|c|c|c|c|}
\hline \multicolumn{6}{|c|}{ Coefficients ${ }^{a}$} \\
\hline \multirow[t]{2}{*}{ Model } & \multicolumn{2}{|c|}{ Unstandardized Coefficients } & \multirow{2}{*}{$\begin{array}{l}\text { Standardized } \\
\text { Coefficients } \\
\text { Beta }\end{array}$} & \multirow[t]{2}{*}{$\mathrm{t}$} & \multirow[t]{2}{*}{ Sig. } \\
\hline & $\mathrm{B}$ & Std. Error & & & \\
\hline (Constant) & .020 & 1.054 & & .019 & .986 \\
\hline$1 \longdiv { \mathrm { CAR } }$ & .077 & .066 & .570 & 1.161 & .310 \\
\hline $\mathrm{NPL}$ & -.045 & .222 & -.100 & -.204 & .848 \\
\hline
\end{tabular}

a. Dependent Variable: ROA

Berdasarkan hasil perhitungan tabel 4.2 di atas analisis regresi linier berganda dengan menggunakan program SPSS 20, diketahui bahwa tabel kolom Unstandardized Coefficients diatas maka nilai $\beta_{1}=0,077 \beta_{2}=-0,045$ sehingga persamaan regresinya adalah : $\mathrm{Y}=0,020+0,077 \mathrm{X}_{1}--0,045 \mathrm{X}_{2}+\mathrm{e}$

\section{Analisis Koefisien Korelasi}

\section{Tabel 4.3}

Analisis Koefisien Korelasi

Model Summaryb

\begin{tabular}{|l|r|r|r|r|r|}
\hline Model & \multicolumn{1}{|c|}{$\mathrm{R}$} & $\mathrm{R}$ Square & $\begin{array}{c}\text { Adjusted R } \\
\text { Square }\end{array}$ & $\begin{array}{c}\text { Std. Error of } \\
\text { the Estimate }\end{array}$ & $\begin{array}{c}\text { Durbin- } \\
\text { Watson }\end{array}$ \\
\hline 1 & $.527^{\mathrm{a}}$ & .278 & -.083 & .42361 & 1.966 \\
\hline
\end{tabular}

a. Predictors: (Constant), NPL, CAR

b. Dependent Variable: ROA

Sumber: data di olah SPSS 20

Berdasarkan hasil tabel 4.3 di atas, dapat diketahui bahwa koefisien korelasi sebesar 0,527\%. jika melihat tabel keeratan korelasi, maka korelasi ini dinyatakan memiliki korelasi yang kuat di karenakan nilai yang didapatkannya berada di interval $0,40-0,59$.

\section{Analisis Koefisien Determinasi}

Tabel 4.4

Analisis Koefisien Determinasi

Model Summary ${ }^{b}$

\begin{tabular}{|l|r|r|r|r|r|}
\hline Model & \multicolumn{1}{|c|}{$\mathrm{R}$} & R Square & $\begin{array}{c}\text { Adjusted R } \\
\text { Square }\end{array}$ & $\begin{array}{c}\text { Std. Error of } \\
\text { the Estimate }\end{array}$ & $\begin{array}{c}\text { Durbin- } \\
\text { Watson }\end{array}$ \\
\hline 1 & $.527^{\mathrm{a}}$ & .278 & -.083 & .42361 & 1.966 \\
\hline
\end{tabular}

a. Predictors: (Constant), NPL, CAR

b. Dependent Variable: ROA

Sumber : data di olah SPSS 20

Berdasarkan hasil tabel 4.4 di atas, nilai R Square sebesar 0,278 atau 27,8\%. Hal ini menunjukkan bahwa variasi variabel independen yang diajukan mampu menjelaskan $27,8 \%$ terhadap variasi variabel dependen (ROA) dan sisanya $72,2 \%$ oleh faktor lain yang tidak diikutsertakan dalam model. 


\section{Pengujian Asumsi Klasik}

\section{a. Uji Normalitas}

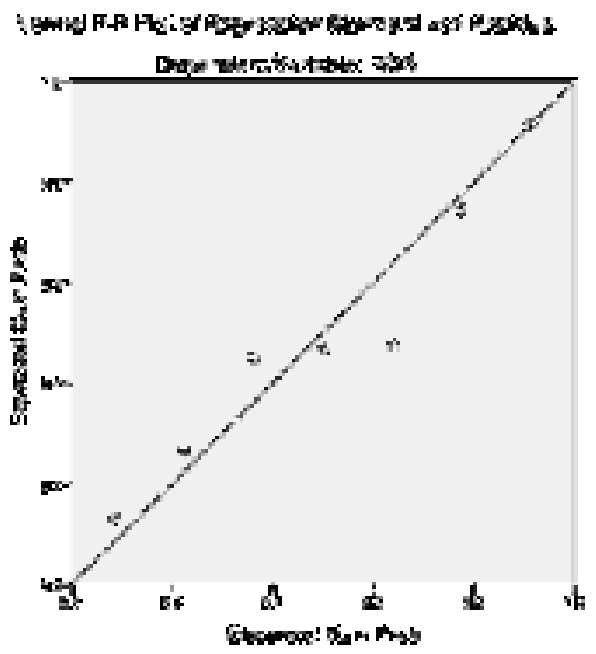

Gambar 4.1

\section{Grafik Normal Probability}

Berdasarkan gambar 4.1 diatas, dapat dilihat bahwa data menyebar disekitar garis diagonal danmengikuti arah garis diagonal. Maka dapat disimpulkan bahwa model regresi ini memenuhi asumsi normalitas.

\section{b. Uji Multikoliniaritas}

\section{Tabel 4.5}

Tabel Uji Multikolinearitas

Coefficients ${ }^{\mathrm{a}}$

\begin{tabular}{|rl|r|r|}
\hline \multicolumn{2}{|l|}{ Model } & \multicolumn{2}{|c|}{ Collinearity Statistics } \\
\cline { 3 - 4 } & Tolerance & \multicolumn{1}{c|}{ VIF } \\
\hline \multirow{3}{*}{$1 \quad$ (Constant) } & & \\
& CAR & .749 & 1.335 \\
& NPL & .749 & 1.335 \\
\hline
\end{tabular}

a. Dependent Variable: ROA

Sumber : data di olah SPSS 20

Berdasarkan tabel 4.5 diatas, pada kolom Tolerance nilai Tolerance masingmasing variabel bebas Capital Adequacy Ratio (CAR) senilai 0.749 dan Non Performing Loan (NPL) sebesar 0.749. semua angka tersebut diatas 0.1. Pada kololm Variance Inflation Factor (VIF) dapat dilihat nilai VIF masing-masing variabel Capital Adequacy Ratio (CAR) senilai 1.135 dan Non Performing Loan (NPL) sebesar 1.135. Nilali VIF dari hasil output SPSS tersebut semua dibawah 10. Jadi, dapat disimpulkan bahwa berdasarkan nilai Tolerance yang diatas 0.1 dan VIF yang dibawah 10, maka dalam penelitian ini tidak terjadi masalah multikolinearitas. 


\section{c. Uji Heteroskedatisitas}

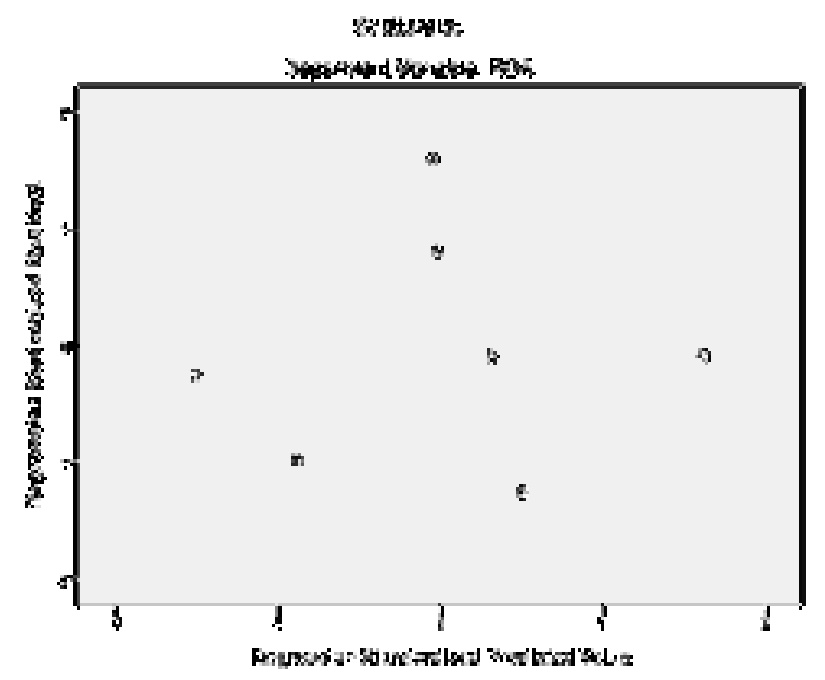

Gambar 4.2

Uji Heteroskedatisi

Berdasarkan gambar diatas, pola titik-titik pada scatterplot regresi menyebar dengan pola yang tidak jelas dan dibawah angka 0 pada sumbu Y maka dalam model regresi ini tidak terjadi masalah heteroskedatisitas.

\section{d. Uji Autokorelasi}

Tabel 4.6

Tabel Autokorelasi

Runs Test

\begin{tabular}{|l|r|}
\hline \multicolumn{2}{|c|}{ Runs Test } \\
\hline & $\begin{array}{r}\text { Unstandardiz } \\
\text { ed Residual }\end{array}$ \\
\hline Test Value & a \\
Cases $<$ Test Value & -.03472 \\
Cases >= Test & 3 \\
Value & 4 \\
Total Cases & 7 \\
Number of Runs & 4 \\
Z & .000 \\
Asymp. Sig. (2- & 1.000 \\
tailed)
\end{tabular}

a. Median

Sumber : data di olah SPSS 20

berdasarkan tabel 4.6 diatas maka di peroleh nilai asymp. Sig (2-tailed) pada uji Runs Test dengan ketentuan sebagai berikut:

Taraf nyata $(\alpha)=0,05$

a. Nilai Asymp. Sig (2-tailed) < dari 0,05 maka terjadi gejala autokorelasi

b. Nilai Asymp. Sig (2-tailed) > dari 0,05 maka tidak terjadi gejala autokorelasi

Berdasarkan tabel diatas maka diketahui nilai Asymp. Sig (2-tailed) sebesar 0,100 lebih besar dari 0,05 maka dapat disimpulkan bahwa tidak terdapat gejala atau masalah autokorelasi pada model regresi. 


\section{Pengujian Hipotesis}

\section{a. Uji Parsial (Uji t)}

Tabel 4.7

Coefficient (Uji t)

Coefficients ${ }^{\mathrm{a}}$

\begin{tabular}{|c|c|c|c|c|c|}
\hline \multirow[t]{2}{*}{ Model } & \multicolumn{2}{|c|}{$\begin{array}{c}\text { Unstandardized } \\
\text { Coefficients } \\
\end{array}$} & $\begin{array}{l}\text { Standardized } \\
\text { Coefficients }\end{array}$ & $\mathrm{t}$ & Sig. \\
\hline & B & Std. Error & Beta & & \\
\hline (Constant) & .020 & 1.054 & & .019 & .986 \\
\hline CAR & .077 & .066 & .570 & 1.161 & .310 \\
\hline NPL & -.045 & .222 & -.100 & -.204 & .848 \\
\hline
\end{tabular}

a. Dependent Variable: ROA

sumber : data di olah SPSS 20

Dari tabel 4.7 diatas hasil output tersebut dapat ditarik kesimpulan sebagai berikut:

1) Pengaruh Capital Adequacy Ratio terhadap Return On Assets.

Berdasarkan hasil pengujian tabel 4.7 variabel (CAR) memiliki thitung $1,161<$ $\mathrm{t}_{\text {tabel }}$ 2,776 maka variabel Capital Adequacy Ratio tidak berpengaruh terhadap variabel Return On Assets. Dengan nilai signifikan variabel (CAR) sebesar 0,310 lebih besar dari 0,05 atau 5\% maka dapat disimpulkan bahwa Ho di terima dan $\mathrm{H}_{\mathrm{a}}$ di tolak. Yang artinya variabel (CAR) tidak berpengaruh signifikan terhadap (ROA) pada PT. Bank Sinarmas Tbk.

2) Pengaruh Non Performing Loan terhadap Return On Assets

Berdasarkan hasil pengujian tabel 4.7 variabel Non Performing loan memiliki $t_{\text {hitung }}-0,052<\mathrm{t}_{\text {tabel }} 2,776$ maka variabel (NPL) tidak berpengaruh terhadap variabel (ROA). Dengan nilai signifikan variabel (NPL) sebesar 0,961 lebih besar dari $0,05 \%$ atau $5 \%$ maka dapat disimpulkan bahwa $\mathrm{H}_{\mathrm{o}}$ diterima dan $\mathrm{H}_{\mathrm{a}}$ ditolak, yang artinya variabel (NPL) tidak berpengaruh signifikan terhadap (ROA) pada PT. Bank Sinarmas Tbk.

\section{b. Uji Simultan (Uji F)}

Tabel 4.8

Uji F (Uji Simultan)

ANOVA ${ }^{\mathrm{a}}$

\begin{tabular}{|c|c|c|c|c|c|}
\hline Model & $\begin{array}{c}\text { Sum of } \\
\text { Squares }\end{array}$ & $\mathrm{df}$ & $\begin{array}{c}\text { Mean } \\
\text { Square }\end{array}$ & $\mathrm{F}$ & Sig. \\
\hline Regression & .276 & 2 & .138 & \multirow[t]{3}{*}{.769} & \multirow{3}{*}{$.522^{\mathrm{b}}$} \\
\hline Residual & .718 & 4 & .179 & & \\
\hline Total & .994 & 6 & & & \\
\hline
\end{tabular}

a. Dependent Variable: ROA

b. Predictors: (Constant), NPL, CAR

sumber : data di olah SPSS 20

Dari perhitungan SPSS tersebut diperoleh nilai $F_{\text {hitung }} 0,769$ sedangkan $F_{\text {tabel }} 6,94$ dengan taraf signifikan 0,522 >0,05 maka nilai signifikan sebesar 0,522 lebih besar dari nilai taraf nyata 0,05 . Dengan demikian dapat disimpulkan bahwa $\mathrm{H}_{\mathrm{o}}$ di terima dan $\mathrm{H}_{\mathrm{a}}$ di tolak, artinya secara simultan tidak terdapat pengaruh yang signifikan secara bersama-sama antara variabel (CAR) dan (NPL) terhadap (ROA) pada PT. Bank Sinarmas Tbk. 


\section{PENUTUP}

\section{A. Kesimpulan}

1. Capital Adequacy Ratio (CAR) secara parsial tidak memiliki pengaruh yang signifikan terhadap Return On Assets (ROA) pada PT Bank Sinarmas Tbk, hal ini dibuktikan dari hasil Uji $t$ diperoleh nilai $t_{\text {hitung }} 1,161<\mathrm{t}_{\text {tabel }} 2,776$ maka variabel Capital Adequacy Ratio tidak berpengaruh terhadap variabel Return On Assets. Dengan nilai signifikan variabel (CAR) sebesar 0,310 lebih besar dari 0,05 atau 5\% maka dapat disimpulkan bahwa Ho di terima dan $\mathrm{H}_{\mathrm{a}}$ di tolak.

2. Secara parsial Non Performing Loan (NPL) tidak memiliki pengaruh yang signifikan terhadap Return On Assets (ROA) pada PT Bank Sinarmas Tbk, hal ini dibuktikan dari hasil Uji $t$ diperoleh nilai thitung $-0,052<t_{\text {tabel }} 2,776$ maka variabel (NPL) tidak berpengaruh terhadap variabel (ROA). Dengan nilai signifikan variabel (NPL) sebesar 0,933 lebih besar dari $0,05 \%$ atau 5\% maka dapat disimpulkan bahwa $\mathrm{H}_{\mathrm{o}}$ diterima dan $\mathrm{H}_{\mathrm{a}}$ ditolak.

3. Secara simultan variabel Capital Adequacy Ratio dan Non Performing Loan secara bersama-sama tidak memiliki pengaruh terhadap variabel Return On Assets pada PT Bank Sinarmas Tbk, hal ini dibuktikan dari hasil $\mathrm{F}_{\text {hitung }} 0,769$ sedangkan $\mathrm{F}_{\text {tabel }} 6,94$ dengan taraf signifikan 0,522 >0,05 maka nilai signifikan sebebsar 0,522 lebih besar dari nilai taraf nyata 0,05 . Dengan demikian $\mathrm{H}_{\mathrm{o}}$ di terima dan $\mathrm{H}_{\mathrm{a}}$ di tolak.

\section{B. Saran}

1. Saran penulis berdasarkan temuan hasil penelitian maka untuk meningkatkan pengelolaan asset yang hendaknya bank dapat lakukan dengan menjalankan fungsi intermediasi yaitu dengan menyalurkan kredit dengan bunga kredit yang lebih rendah serta didukung dengan penemabahan kantor cabang, modernisasi IT dan tenaga kerja yang handal

2. Manajemen Bank harus mampu meningkatkan terus profitabilitas bank supaya bank bisa mendapatkan laba yang tinggi sehingga bank mendapatkan dana yang dapat digunakan untuk kegiatan operasional bank.

3. Hasil penelitian ini dapat dijadikan sebagai bahan pertimbangan dalam pengambilan keputusan tentang kesehatan bank serta dapat menjadi cerminan untuk dapat mengambil keputusan yang tepat di dalam mengelola asset.

\section{DAFTAR PUSTAKA}

Aziz, A. H. (2012). Metode Penelitian dan Teknik Analisis Data. Jakarta: Salemba Medika Copland, J. F. (2010). Manajemen Keuangan. Jakarta: Bina Rupa Aksara

Coulter Mary, R. (2013). Manajemen Edisi Kesepuluh. Jakarta: Erlangga

Darmawi, H. (2011). Manajemen Perbankan. Jakarta: Bumi Aksara

Dendawijaya, L. (2009). Manajemen Perbankan . Jakarta: Ghalia Indonesia

DN, G. (2012). Dasar-dasar Ekonometrika buku kedua Edisi 5. Jakarta: Salemba Empat Engkoswara. (2010). Paradigma Manajemen Pendidikan. Bandung: Yayasan Amal Keluarga ahmi. (2012). Analisis Kinerja Keuangan. Bandung

Francis Tantri, A. (2014). Manajemen Pemasaran . Depok: PT Raja Grafindo Persada

Ghozali, I. (2013). Aplikasi Analisis Multivariate dengan Program IBM SPSS. Yogyakarta Universitas Diponegoro

Greuning, H. V. (2013). International Financial Reporting Standard : Sebuah Panduan Praktis. Jakarta: Salemba Empat

Hadi, S. (2013). Analisis Statistika. Yogyakarta: Pustaka Pelajar 
Harahap, S. S. (2009). Analisis Kritis atas Laporan Keuangan. Jakarta: PT Raja Grafindo Persada

Harmono. (2009). Manajemen Keuangan. Jakarta

Houston, B. d. (2010). Dasar-Dasar Manajemen Keuangan Buku 1 (Edisi 11). Jakarta Salemba Empat

Ismail. (2009). Manajemen Perbankan. Kencana Cetakan

Kasmir. (2010). Pengantar Manajemen Keuangan. Jakarta

Martono, A. H. (2010). Manajemen Keuangan . Yogyakarta: Ekonisia

Melayu, H. (2009). Manajemen: Dasar, Pengertian dan Masalah. Jakarta: Bumi Aksara

oeddin, A. (2010). Melacak Kredit Bermasalah Cetakan Pertama. Jakarta: Pustaka Sinar Harapan

Munawir. (2010). Analisis Laporan Keuangan Edisi 4. Yogyakarta: Liberty

Safroni. (2012). Manajemen Pelayanan . Surabaya: Aditya Media Publishing

Santoso, S. (2012). Analisis SPPS pada Statistik Parametrik. Jakarta: PT Elex Media Komputindo

Santoso, T. B. (2009). Bank dan Lembaga Keuangan Lain. Jakarta: Salemba Empat

Solihin, I. (2009). Pengantar Manajemen. Jakarta: Erlangga

Sudana, I. M. (2011). Manajemen Keuangan Perusahaan. Jakarta : Erlangga

Sudirman, I. W. (2013). Manajemen Perbankan Menuju Bankir Konvensional yang Profesional. Jakarta: Kencana

Sugiyono. (2014). Metode Penelitian Kuantitatif, Kualitatif, dan Kombinasi. Bandung: Alfabeta

Sutrisno. (2012). Manajemen Keuangan Teori, Konsep dan Aplikasi. Yogyakarta: Ekonisia

Tandelilin, E. (2010). Portofolio dan Investasi Teori Dan Aplikasi Edisi Pertama. Yogyakarta: Kamisius

Taswan. (2012). Manajamen Perbankan Konsep, Teknik, dan Aplikasi Edisi Kedua Yogyakarta: UPP STIM YKPN

Usman, S. D. (2013). Manajemen. Jakarta: Erlangga

Veitzal, R. (2013). Manajemen Sumber Daya untuk Perusahaan dari Teori Ke Praktek Bandung: PT Raji Grafindo Persada

Wild, S. (2012). Analisis Laporan Keuangan. Jakarta: Salemba Empat 